\title{
Knowledge Management and the Governmental Organizations
}

\author{
${ }^{1}$ Rahil Asadi, ${ }^{1}$ Larisa Mihoreanu, ${ }^{2}$ Vasilica Georgiana Radu \\ ${ }^{1}$ Bucharest University of Economic Studies, POLITECHNICA Univ. Bucharest
}

\begin{abstract}
Nowadays, the concept of Knowledge Management (KM) is gradually being recognized in governmental establishments which are seeking to deploy their own KM system and make the most of their existing knowledge in policymaking by creating and maintaining a competitive advantage in the domestic and international environment. Knowledge is a primary resource featured to provide a competitive advantage to any organization that recognizes and incorporates it efficiently in its processes. This article aims to review the knowledge management value and pillars by describing its cycle and highlighting its importance for governmental organizations. Knowledge management will begin and proceed from within organizations. In this article, a computational model is proposed where the organizations will accomplish this aim by developing this model and analyzing the components that influence it. The obstacles and difficulties of implementing and deploying knowledge management in governmental organizations as well as suggested solutions are also discussed.As a result, the importance of knowledge management and the governmental organization's need for knowledge management to achieve the profitability has been demonstrated, along with recommendations for decision-makers to enhance the efficiency of the knowledge management implementation and scale up the gain of a lasting competitive advantage within national and international environments.
\end{abstract}

Keywords: Knowledge, Knowledge Management, Governmental organizations

JEL Classification : D74, D83, M00, 020

How to cite: ASADI, R., MIHOREANU, L., RADU, V.G., (2020), Knowledge Management and the Governmental Organization s, Journal of Economic Development, Environment and People, 9(3), p.75-82, DOI: https://doi.org/10.26458/jedep.v9i3.663

\section{Introduction}

Within a modern organization, where employees focus mainly on intellectual tasks in their work, Knowledge Management (KM) defines not only but the people's constant learned capability to rethink resources and creative forces to be applied inside the organization (Sensky, 2003). The existence of an open communication environment allowing people to collaborate and freely exchange ideas within the organization is one of the basic conditions needed for this one to constantly grow up, by facilitating the learning process of all its members and leading the pathway towards an agile organization (Kettunen \& Laanti, 2017). 


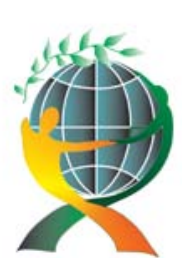

\author{
(online) = ISSN $2285-3642$ \\ ISSN-L = $2285-3642$ \\ Journal of Economic Development, Environment and People \\ Volume 9, Issue 3, 2020
}

URL: http://jedep.spiruharet.ro

e-mail: office jedep@spiruharet.ro

All through this dynamic process, organizations utilize knowledge management as a business strategy to help the staff to adapt to the changing and competitive environment around them and to adhere quickly to this collective and evolving transformation.

\title{
2. Knowledge Management
}

Knowledge has been always a reliable and outstanding device to sustaining the competitive advantage for those establishments able to manage and integrate it at an organizational level. KM represents the process by which an organization can generate wealth from its knowledge or intellectual capital (Belasen, 2000). The years of '80s brought to light a new movement of business professionals generated by the need of higher quality and emphasizing that all employees must use their intellectual power to improve it while the reengineering decade of the '90s characterized by the use of technology to improve the business processes to reduce the costs. The 2000 s have been dubbed the decade of knowledge management [Dieng-Kuntz \& Matta, 2002].

In a 1994 article by Fortune Magazine, Tom Stewart reminded companies to value what they know (the intellectual capital) more than what they have (the material capital). Surveys show that knowledge management is a topic born and raised in the private sector and has little to say about the background of knowledge management in government agencies [Cong \& Pandya, 2003]. In 2005 Castañeda and Pérez reviews the background of knowledge management in government organizations outlining that KM is "in the early stages of government agencies" and "special attention should be paid to it". They believe that knowledge management is the gathering of knowledge, intellectual capabilities, individuals' interactions within an entity, and rendering them retrievable as an organizational advantage. According to Neuman [1997] knowledge management is a set of phenomena that involves the creation, dissemination, and application of subjective and objective knowledge in an organization. To understand those meanings correctly, apart from data and information it is needed to clarify and describe knowledge.

- Data: represents reality linked to a case or an object within a specific context, without having relations with other items.

- Information: is shaped by adding new context and interpretations to the data and by linking them to each other.

- Knowledge: contributes to the natural development of facts by adding perception and memory to information. Summing up (the accumulation) of basic information helps in expertise. Knowledge in this case can be defined as insight from information and data that can be effective and divisible in different ways and different conditions. Knowledge is minimizing the collection and reading of information, does not increasing access to information.

For the organizations, knowledge is in Peter Drucker's view [1994], the only "source of sustainable competitive advantage" for the future. Knowledge is unique in the sense that the more widely is used as a resource the more multiplies itself, bringing more value to the owner. 


\author{
(online) $=$ ISSN $2285-3642$ \\ ISSN-L = $2285-3642$ \\ Journal of Economic Development, Environment and People \\ Volume 9, Issue 3, 2020
}

URL: http://jedep.spiruharet.ro

e-mail: office_jedep@spiruharet.ro

Public sector organizations appear to have been slow to access this enormous resource, due to its easy and quick access to government credits [Chambers, 1993].

At the organizational level, knowledge management provides the following benefits:

- Promote the organization's performance through increased efficiency, productivity, quality, and innovation.

- Provide greater access to the knowledge of their employees, organizations make better decisions, sharpen their processes, reduce work duplication, increase creativity and innovation, achieve high integration and collaboration.

- In the public sector, knowledge management practices can reduce the cost of business and enhance customer service.

- As knowledge transfer is increasingly recognized as a source of added value, organizations perceive knowledge management as a competitive advantage strategy field.

Smart organizations capitalize collectively on its members' knowledge and apply results for realworld solutions transforming social capital into organizational competence. This type of organizational culture enhances learning by training, consulting, supervising, collaborating, and trusting rather than competing with one another [Turner \& Baker, 2017]. Figure 1 illustrates the application of knowledge management in the administration of public affairs. According to O'Sullivan (2008), each section separately affects the administration of public affairs and each has to be independently reviewed and studied [Wiig, 1997].

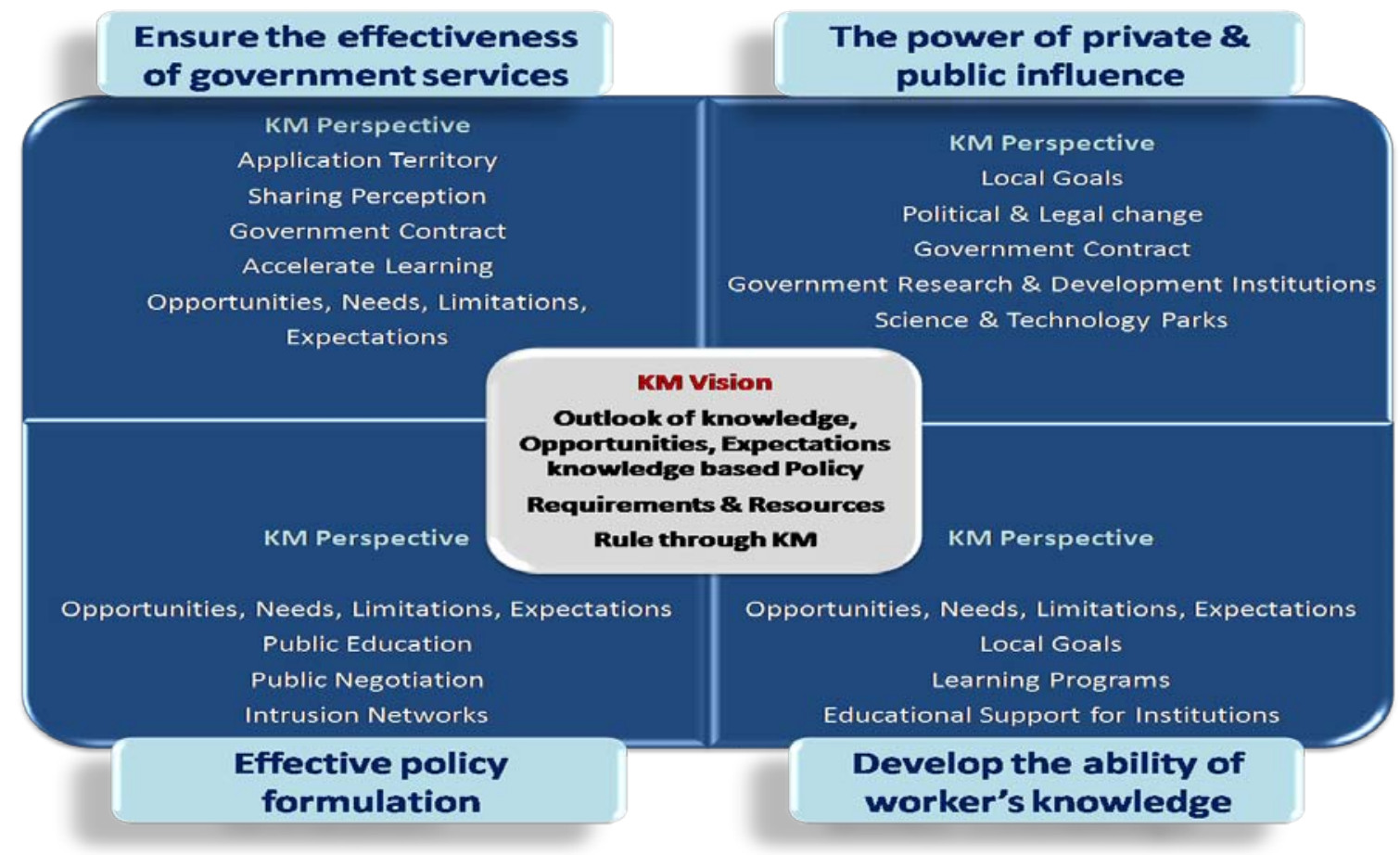




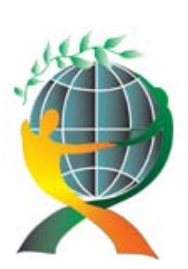

\author{
(online) = ISSN $2285-3642$ \\ ISSN-L = $2285-3642$ \\ Journal of Economic Development, Environment and People \\ Volume 9, Issue 3, 2020
}

URL: http://jedep.spiruharet.ro

e-mail: office jedep@spiruharet.ro

Fig.1: The application of KM in the administration of government organizations. After O'Sullivan (2008)

\title{
3. Problem statement
}

Knowledge management is the process or activity of creating, acquiring, capturing, sharing, and applying knowledge wherever it exists to enhance learning and performance in organizations. The governmental organizations and their environment in which they operate have changed drastically. In order to adapt to a changing and competitive environment, public organizations need to reform their structure, to become more flexible than ever before and they also need to acquire more sophisticated ways to manage and increase their knowledge resource. Therefore, public organizations can achieve this goal by effectively controlling their knowledge cycles (stages of knowledge production and dissemination) and supporting more effectively the social processes that lead to knowledge creation. Knowledge has become a crucial determinant of competitiveness in the public sector.

Service and policy-making are the two main functions of governments. In a knowledge-based economy, governments are increasingly faced with international and even national competition. The complex economic, political and cultural challenges of today's world are unprecedented, driving a rapid pace of change and an environmental dynamic pressure far greater than one might imagine. In today's complex social context of increasing communication and action speed, policymakers have an important responsibility that crosses the boundaries of countries. They need new tools and methods to adapt their decisions to the environment, to achieve new goals, and incorporate new knowledge into their policy-making activities [O'Sullivan, 2008]. Private companies produce goods and provide services that compete directly with those produced by the public sector. Education, knowledge, security, and science are among the areas of competition between the two sectors.

The retirement of civil servants, as well as their transfer between departments or institutions, create new challenges for the survival of knowledge in the organization and subsequent for the training of new employees. Over time, current government employees will retire and this is a major problem that many governments will be facing. Government agencies need to retain the knowledge of senior staff with the initiative because otherwise, it would be difficult to continuously provide services to the public. The increasing number of knowledge-based citizens is forcing the government to expose the knowledge created and updated. Knowledge management principles state that the most important valuable resource of any organization is the knowledge of its employees. This focus is driven by the increasing momentum of change in the organization and society at large.

Knowledge management capabilities enhance the efficiency of the government and its competitiveness in a changing environment. The public sector and non-governmental organizations must meet these challenges and make the best use of opportunities from globalization, the knowledge-based economy, and the spread of information and communication technology; otherwise, this will mean losing the opportunities offered by knowledge management.

\section{KM's Role and Application in the Government Organizations}




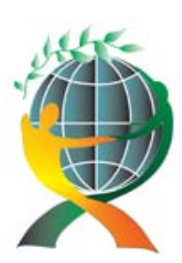

\author{
(online) = ISSN $2285-3642$ \\ ISSN-L = $2285-3642$ \\ Journal of Economic Development, Environment and People \\ Volume 9, Issue 3, 2020
}

URL: http://jedep.spiruharet.ro

e-mail: office_jedep@spiruharet.ro

The Organization for Economic Co-operation and Development, within the first World Forum on Key Indicators, decided to examine the importance and necessity of applying knowledge management in all executive organization $\mathrm{s}$ to improve the performance of government agencies and concluded that this change was driven by the multiple reasons (2005), such as:

Globalization. The process of globalization affects public sector management. Like other social or scientific theories in government administration, the diffusion of technology effects occurs so rapidly that national boundaries are becoming more and more prevalent. The new era is linked to technologies such as human intelligence on global networks, not just artificial intelligence and specialized systems. Networks, where people's knowledge and insight, their intelligence, and ingenuity, their creativity, and innovation will be brought together to advance human society are already a reality. One manifestation of globalization within the countries will be to diminish the distinction between the public and private sectors [Astrauskas \& Guérard, 2016].

Linearization and Policy. Porter [1990] believes that a wide range of government policies somehow influences national superiority. These include education policy, tax policy, health policy, anti-monopoly policy, environmental policy, regulation policy, financial and monetary policy, and many other policies. The new trend seems to be in the direction of the knowledge acquisition policy. In modern policy-making, the mere use of positivism in the acquisition of knowledge has been criticized and tendencies toward phenomenological approaches and theories of disorder (chaos) are being observed and thus given the nature of knowledge. And especially the latent knowledge that is subjective and also contains values, experiences, and beliefs, the importance of knowledge in new policy orientations. Therefore policymakers, no matter the economic development of their country, imperatively need adequate knowledge improvement to sustain their best policy and harmonize the national knowledge with the international one in the field.

Size of the government. The governments and their bureaucracy [Blau \& Meyer, 1993] have always been the source of some unrest in society. Experts see the use of bureaucratic tools as a factor in stabilizing the status quo and ineffectiveness. Attacks against the size and practices of the public sector have had an impact on the process of government downsizing and changing management. Today, the downsizing of government and the move from vetting to sovereignty have been almost everywhere on the agenda of governments.

Private organization. The public sector has always borrowed from the private sector. Many of the principles of the organization of public administration of the last century have been imitated by the private sector [Blau and Meyer, 1993]. The capacities and capabilities of the private sector increase daily in many fields, enabling them to employ specific techniques such as process reengineering, comprehensive quality management, return added value, strategic management accentuating the gap between public and private organizations' efforts, and results [Grzegorczyk \& Ghiorghiţă, 2017].

Increasing knowledge of people. Unlike past societies, a high percentage of today's people are highly skilled and trained and have become a valuable resource for organizations. Citizen centricity seems to be gradually becoming one of the main adopted strategies of modern public 


\author{
(online) = ISSN $2285-3642$ \\ ISSN-L = $2285-3642$ \\ Journal of Economic Development, Environment and People \\ Volume 9, Issue 3, 2020
}

URL: http://jedep.spiruharet.ro

e-mail: office jedep@spiruharet.ro

administration. Under the generic term "pro-active citizens" the groups of effective contributors, the Citizens of Knowledge, have a greater impact on government agencies.

The exit of knowledge forces from government organizations. Knowledge is a social and human subject and unlike information that doesn't rely only on technology. The departure of the professional forces well-trained under national funding from government organization $s$ (due to either retirement, transfer, or migration) deprived the public institutions of their most important resource, the knowledge of their staff; therefore, appropriate knowledge management models need to be utilized to prevent this from happening.

\title{
5. Conceptual Model
}

We summarise in the second figure of this article, a conceptual model as a theoretical and systematic overview of knowledge management within government organizations. Knowledge management is affecting the process that encompasses all the factors and variables considered and government organizations can apply it to increase their capability, improve performance, and increased efficiency to compete nationally and internationally with other organizations.

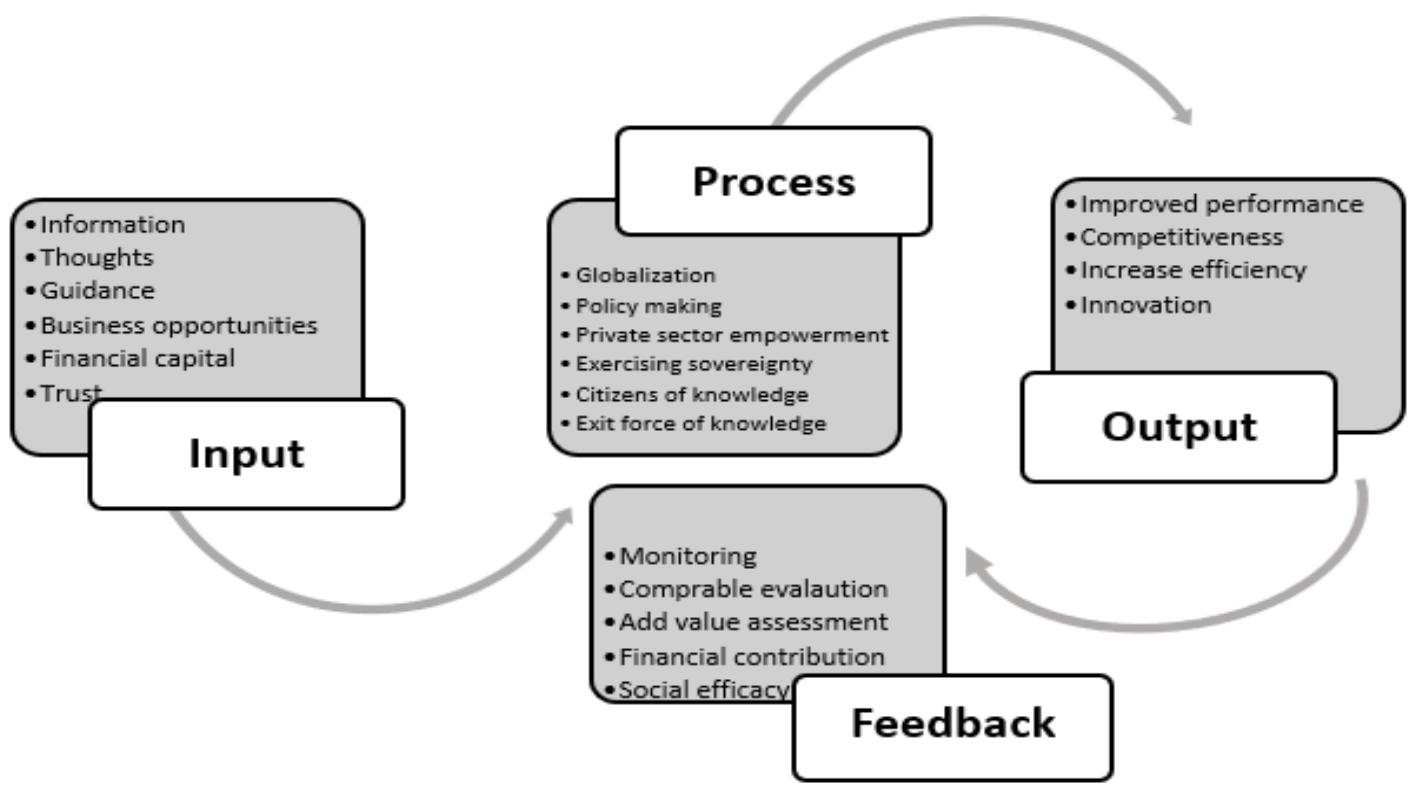

Fig.2. A personal approach of Chambers KM Cycle in the Government Organizations (1993)

A good example of implementation of the KM concept into public establishments' organization happens these days when the market and society are overwhelmed by the coronavirus COVID 19 and its consequences. Both organizational and societal sides of knowledge management have been highly associated with the flexible development continuity and surviving issues by the creative 


\author{
(online) = ISSN $2285-3642$ \\ ISSN-L = $2285-3642$ \\ Journal of Economic Development, Environment and People \\ Volume 9, Issue 3, 2020 \\ URL: http://jedep.spiruharet.ro \\ e-mail: office jedep@spiruharet.ro
}

implementation of information technologies of which use considerably increased these days, under COVID 19's attack against the world. Sides of the excellent model have been put in practice and shared by people, associations, universities and executive organizations under a larger sociotechnical and financial perspective, managed by the care for society and citizens, by the day of tomorrow, by the faith that together is stronger than loneliness inside a world community. Most of the energies have been directed towards the education and health sectors, towards the human forces involved, proving those executive decisions, managerial administration and leadership can play a critical but creative role in establishing the dynamic context for the effective complex assimilation of knowledge management practices and new tools.

\title{
6. Conclusion
}

Based on the material presented, we can say that knowledge management application is still in its infancy; the early stages of this new scientific branch, as an intelligent tool for analyzing facts and transacting globalization, policymaking, private sector empowerment do not provide the full options of harnessing the existing knowledge in individuals and leaders to increase both collective contribution and well-being. The government size and sound policy may also contribute to citizen knowledge and force increasing. Therefore, public and governmental organizations should pay particular attention to knowledge management implementation mostly in the hot sectors of activity (education, health). And become aware of the power of knowledge to maintain long-term excellence in the competitive arena and improve economic efficiency and societal efficacy by deploying knowledge management. When governments don't carefully consider the knowledge management implementation especially in the sectors of activity in suffer, then the consolidation of the decision and information systems fail while socio-economic differences increase.

\section{References}

[1] Astrauskas, Algirdas and Guérard, Stéphane, (2016), Local Autonomy in the 21st Century. Between Tradition and Modernisation. Centre d'Études et de Recherches Administratives, Politiques et Sociales (CERAPS). Institut Universitaire Varenne. Bayonne. https://lilloa.univ-lille.fr/handle/20.500.12210/14785

[2] Belasen, Alan. (2000). Leading the learning organization: communication and competencies for managing change. Albany, NY: State University Press. ISBN 978-0-7914-4367-5.

[3] Blau Peter Michael and Meyer, M.W. (1993). Bureaucracy in modern society. $2^{\text {nd }}$ Eds. New York: McGrawHill.

[4] Castañeda, D. and Pérez, A., (2005), Cómo se produce el aprendizaje individual en el aprendizaje organizacional? Una explicación más allá del proceso de intuir, Revista Interamericana de Psicología Ocupacional, Vol 24, No 1, pp 1-15.

[5] Chambers, R. (1993), Challenging the professions: frontiers for rural development. London: Intermediate Technology Publications, ISBN : 1853391948. 


\author{
(online) = ISSN $2285-3642$ \\ ISSN-L = $2285-3642$ \\ Journal of Economic Development, Environment and People \\ Volume 9, Issue 3, 2020 \\ URL: http://jedep.spiruharet.ro \\ e-mail: office jedep@spiruharet.ro
}

[6] Cong, X. and Pandya, K.V. (2003), Issues of Knowledge Management in the Public Sector. The Electronic Journal of Knowledge Management, 1, 25-33.

[7] Dieng-Kuntz Rose and Matta, Nada. (2002). Knowledge Management and Organizational Memories. Boston, MA: Springer US.

[8] Drucker, P. (1994). The age of social transformation. The Atlantic Monthly, 274: 53-80.

[9] Grzegorczyk Adam and Ghiorghiţă Eugen, (2017), Knowledge management as a strategic business resource, JEDEP, 6(2):63-72. file:///C:/Users/user/Downloads/JEDEP21_6Ghirghita_p63-72.pdf.

[10]https://www.researchgate.net/publication/241699113 Redefining Knowledge Management to Deliver Competitive Advantage.

[11] Kettunen, P. and Laanti, M. (2017). Future software organizations - agile goals and roles. Eur J Futures Res 5,16 https://doi.org/10.1007/s40309-017-0123-7

[12] Newman Victor, (1997), Redefining Knowledge Management to Deliver Competitive Advantage, Journal of Knowledge Management, 1(2):123-128, June,

[13] O’Sullivan, K. (2008). Strategic knowledge management in multinational organizations. Hershey, Pa: Information Science Reference.

[14] Porter, Michael, (1990), The Competitive Advantage of Nations, Harvard Business Review, International Business March-April.

[15] Sensky, Tom (2002). Knowledge Management. Advances, Psychiatric Treatment. 8(5): 387-395. doi:10.1192/apt.8.5.387.

[16] Stewart Tom, (1994), Your Company's Most Valuable Asset: Intellectual Capital. Fortune: 130, 68-70.

[17] Turner, John R. and Rose Baker, (2017), Team Emergence Leadership Development and Evaluation: A Theoretical Model Using Complexity Theory, Journal of Information \& Knowledge Management Vol. 16, No. 02, 1750012, https://www.worldscientific.com/doi/abs/10.1142/S0219649217500125

[18] Wiig, K. M. (1997). Knowledge management: An introduction and perspective. The Journal of Knowledge Management, 1(1), 6-14.

[19] World Forum on Key Indicators. (2005). Statistics, knowledge and policy: key indicators to inform decision making. OECD. Paris. 